\title{
Contact of Dialect Clusters: The Malay Peninsula and Sumatera
}

\author{
Asmah Haji Omar, Salinah Jaafar, Siti Ruhaizah Che Mat \\ University of Malaya, Kuala Lumpur, Malaysia \\ Email: asmahomar@um.edu.my
}

Received 20 August 2015; accepted 10 October 2015; published 13 October 2015

Copyright (C) 2015 by authors and Scientific Research Publishing Inc.

This work is licensed under the Creative Commons Attribution International License (CC BY). http://creativecommons.org/licenses/by/4.0/

c) (i) Open Access

\begin{abstract}
Contact between speakers of clusters of Malay dialects of the Malay Peninsula and Sumatera has been going on from historical times until today. This study discusses contacts as reflected in the literary genres of the syair and the hikayat. A research was conducted on a real life situation of the contact of the Bengkulu dialect cluster of Sumatera and that of the southern peninsula Malay dialect in a Bengkulu settler community in the latter region, to assess the receptivity of the speakers of the minority settler community of the norms of the host region. The findings showed that although there was adaptation on the part of the minority community, it did not come readily. Norms that determine the preferred use and usage of language, as well as the social pragmatics of adaptation are the motivating factors for acceptance. Stability of the minority as part of a larger community leads to uninhibited awareness of the traditions of the (former's) parent community, which in turn motivates a regeneration of erstwhile practices.
\end{abstract}

\section{Keywords}

Dialect Cluster, Cluster Contact, Settler Community, Host Community, Regeneration

\section{Introduction}

The Malay language has usually been given the label of lingua franca of insular Southeast Asia, as it was and is the language in the ports of the various islands which together make up Malaysia and Indonesia. However, besides this lingua franca which is sociolinguistically Low Malay, there is High Malay which is the national language of both these countries, and which has a history of being the language of Malay Kingdoms long before the existence of these two nation states, dating back to the seventh century C.E. The earliest written form of Malay is on four stone inscriptions belonging to this era, found in the southern part of Sumatera (Palembang and Jambi), and the adjacent Bangka island. 
This study is about the meeting of Malay dialects of different dialect clusters across the Straits of Melaka. It is given in two sections. The first is a study of cluster contact as reflected in the literary genres of syair and hikayat, while the second is a real life study of contact of a Bengkulu settler community and the local Malays in the Malay Peninsula (henceforth, the Peninsula).

\section{Dialects and Dialect Clusters}

A dialect is a different form or variety out of a number of forms or varieties of a single language. Differences between one dialect and the other lie in the ways words are pronounced, and in certain lexical items which symbolise the same concepts. However, these differences are not to the extent of obstructing mutual intelligibilty between speakers of different dialects of the same language.

As dialects are also defined by geographical borders, mutual intelligibilty can be gauged according to the geographical distance between speakers of different dialect areas. The closer they are, the readier is mutual intelligibilty between them. Those further apart may take a little bit more time to get used to one another's way of speaking. For example, in an interaction between two speakers, one using the Johor dialect and the other the Kelantan dialect, both of the Peninsula, the former may stumble in the first few minutes of their conversation during which time he is able to figure out the phonological aspects which make their pronunciations different; and after internalizing the differences the conversation takes a smooth turn. There may be a few expressions which do not exist in his language, but this would not cause a breakdown in communication between them. The country's leaders have been known to resort to their own dialects in spontaneous speech. The two most well-known ones (wth this habit) were the the first Prime Minister of Malaysia, Tunku Abdul Rahman, and the fourth, Dr. Mahathir Mohamad, both from Kedah, and their message got across to the people without much difficulty.

Just as "language" is an abstract concept for different forms of speech connected to one another, so is "dialect”. As an example, the Kedah dialect of the Malay Peninsula represents a number of varieties of speech systems, spreading from Satun (Southern Thailand) in the north to Taiping (Perak) in the south, and from the islands of the northwest coast to Grik (Perak) in the east. But Kedah dialect speakers from wherever they are do not find difficulty in understanding one another, as the differences in the speech of their localities do not hinder a smooth communication between them ${ }^{1}$.

In dialectology, varieties within a dialect are known as "subdialects", and the localities attributed to the subdialects are known as "subregions". Prose and verse forms have been produced in subdialects, but they are generally attributed to the dialect which representsthese varieties. For instance, Hikayat Terong Pipit (in prose form), and Syair Sultan Maulana (a verse form) are hailed as written in the Kedah dialect, and rightly so. But a Kedah dialect speaker is able to detect features of the northern Kedah variety in the former, while the latter can be attributed to that of the southern variety. This means that when an item of traditional literature is said to be in a particular dialect, it is actually a product of a subdialect of this dialect. Romances, folktales, and various types of verse forms of the Malay world which today are placed in the category of classical Malay literature are in fact products of subregions of dialects, hence subdialects. In such texts, speakers of subdialects are able to identify features which belong to their subregion and those which are not. To avoid the confusion brought about by the notions "dialect" and "subdialect", we propose to use the term "dialect cluster" in place of the traditional usage of “dialect”, and the latter to replace "subdialect”. Hence a region may have a number of dialect clusters, and each cluster consists of members which are known as dialects.

The notion "dialect" in non-academic usage seems to refer to a form of speech "with no corresponding written form, or those used by uneducated people” (Petyt, 1980: p. 11). On the contrary, Malay dialects in the Peninsula and Sumatera have functioned not only as mediums of literary genres as shown above, but also as the language of governance. To the Malays there is no stigma attached to this form of speech. In fact people in different dialect areas have a certain pride in their dialectal heritage. By choosing the terms "dialect” and "dialect cluster" in this study, we avoid using "subdialect” for simplicity of reference, and at the same time pre-empting any negative notion that might be attached to the last-mentioned.

With the definitions of "dialect” and "dialect cluster" given above, the Peninsula dialect clusters are: i) the northwest cluster generally known as the Kedah dialect, as defined above ii) the Perak or the Parit cluster of the west coast of Perak; iii) the northeast cluster of Kelantan and Terengganu dialects; iv) the central cluster

${ }^{1}$ For the varieties of single dialects spoken in the Malay Peninsula, refer Omar, 2008: Chapters 9-18. 
covering Pahang; v) the southern cluster of Selangor, Melaka and Johor; and vi) the Minang cluster of Negeri Sembilan and South Selangor. The last-mentioned is a relatively new-comer resulting from the migration of speakers from Minangkabau in the nineteenth century who now occupy almost the whole of Negeri Sembilan, and another mass migration in the 1960s also fromthe same source occupying a sizeable area in the southern part of Selangor (Omar et al., 2012), thus creating an interruption in the spread of the central cluster from Perak to Johor.

Sumatera with a larger expanse of land-mass, compared to the Peninsula, consists of Malay dialect clusters, which can be identified according to their areas of spread: i) the east coast cluster, from Medan to the Riau mainland; ii) the central cluster covering Minangkabau, Kampar and Siak; iii) the southern cluster covering Palembang, Jambi and adjacent areas; and iv) the southern west coast cluster covering Bengkulu, Kerinchi, and adjacent areas. Members within a single cluster have charted their own histories of being used as High Language. For example, the Minangkabau dialect in the central cluster is rich with fine verse forms, a famous example being the tambo which relates the history of Minangkabau with rules and ethics in the governance of the community. The dialect of the Bengkulu Province, specifically the variety spoken in Mukomuko, is also used in the syair verse form, e.g. the Syair Mukomuko (see Kathirithamby-Wells \& Hashim, 1985).

When referring to dialects and dialect clusters, a point to be remembered is that in the Malay language of Malaysia, "dialect" is referred to as loghat, an Arabic loan, as opposed to bahasa "language". The speakers indicate the separation of the two in expressions, such as "bahasa Melayu loghat Kedah", "bahasa Melayu loghat Terengganu", etc. In Sumatera, and hence all over Indonesia, the word bahasa refers to both language and dialect, as used in the expressions, bahasa Indonesia, bahasa Melayu, bahasa Riau, bahasa Kampar, bahasa Minang, bahasa Jambi, bahasa Palembang, bahasa Bengkulu, etc., thus blurring the already blurred division of language and dialect. As seen in these Indonesin examples, a speech system is known as bahasa, be it a dialect, a subdialect, or a language, and is identified with a locality or a region. However, except in reference to the national language which is bahasa Indonesia, the term bahasa daerah "provincial language" is usedfor clarity for all speech systems that that have particular geographical contexts.

The expression bahasa Malaysia (language of Malaysia), modelled on bahasa Indonesia, to replace bahasa Melayu, has not been well accepted by the Malays, who are native speakers of the language, and who feel that the language is part of their ethnicity. In addition, maintaining the name bahasa Melayu as the name for the national language is well entrenched in theMalayan/Malaysian Constitution.

\subsection{Cognate Count and Actual Speech Forms}

As mentioned above, mutual intelligibilty is a criterion used by linguists in determining the relationship between two speech systems, whether they are dialects of the same language, or two heterogeneous languages. There is another method of determining the relationship, which is used in lexicostatistics, and that isthrough cognate count based on the Swadesh list of basic core vocabulary, also known as culture-free vocabulary, of either 100 or 200 such words. A count of $86 \%$ cognates and above between two speech systems indicate that they are dialects of one and the same language, while with $85 \%$ and belowthey are heterogeneous languages.

We have worked on the cognate counts of speech systems under consideration. Those that have been labelled as dialects far exceed the $86 \%$ cognate count in their relationship with one another. Examples of these counts are: Bengkulu-Kerinci: 90\%; Bengkulu-Malay: 90\%; Minangkabau-Malay: 93\%.

Cognate count applies only as a first step in determining the status of a speech system in its comparison to another, whether the two are dialects of a single language, or two different languages. From the limited corpus used for the purpose, the most one can get is a picture of certain aspects of the phonology and the lexical words in the lists used in the comparison. A broader picture of the systems compared should be based on a much larger corpus, which should include texts, spoken or written.

The Syair Mukomuko mentioned above is said by its editors to be written in the Minangkabau dialect based on the presence of the vowel /a/ in place of the the schwa vowel /a/ in standard Malay, as in the pairs /basar/ (Min.)—/bəsar/ (Std. Mal) "big"; /padan/ (Min.)—/pəday/ (Std. Mal.) "sword". The editors are also of the opinion that there were inconsistencies in the use of the Minangkabau word forms (Kathirithamby-Wells \& Hashim, 1985: p. xiii). However, it is not feasible to determine the phonological features of a text written two centuries ago and especially in the Jawi script, as done by the editors of Syair Mukumuko. So the solution is to look at the lexical items consisting of the general vocabulary of nouns, verbs and adjectives, idiomatic 
expressions, personal references, and place names. In actual fact this particular text is written in standard Malay with a number of lexical items from Mukomuko, a dialect of the Bengkulu cluster. The text is also interspersed with words from Minangkabau, but these are too few to make it a Minangkabau text.

The meeting of Bengkulu and Minangkabau clusters in the text was due to two factors: geographical proximity, and historical link. The latter is explained by Marsden (1811, 1966: pp. 353-354), as follows²:

Among the earliest dismemberments of the Menangkabau empire was the establishment of Indrapura as an independent kingdom... From the ruins of Indrapura has sprung the kingdom of Anak-sungei, extending, along the sea-coast, from Menjuta river to that of Urei. Its chief bears the title of sultan, and his capital, if such places deserve the appellation, is Moco-moco. (Italics are from the original text).

Looking at the current map of Sumatera with its provinces, the Bengkulu province is surrounded by other provinces, characterised by the presence of other dialect clusters, i.e. the eastern and the southern clusters. As has been said previously, speech systems bordering clusters are likely to influence one another.

Syair Mukumuko is also a case of the meeting of the Bengkulu cluster with the Johor-Riau cluster. This fact is found in the writer himself, Raden Anom Zainal Abidin, who by his own admission in the syair was a grandson of the Sultan of Madura, an island to the north of Java, and he himself had married the elder daughter of Sultan Mukomuko. (Verse 4 of the syair). He must have understood the Bengkulu and the Minangkabau varieties but not well enough to use them to compose a description of an event, in this case the death and funeral of his wife's younger sister. The text shows that he was very proficient in the standard Malay that was used as High Language in the whole of the Malay Archipelago in official letters and various literary forms, and that was the variety known as the Johor-Riau dialect. This dialect was the norm in official and literary usage of Malay all over the Malay Archipelago.

In the same way, the Syair Perang Siak which is the story of the Malay kingdom in Siak and Minangkabau of the eighteenth century has very little to show in terms of features of the Minangkabau cluster. The text can be passed for one witten in Johor, giving justification that this was the variety preferred for this literary genre (Goudie, 1989). The Syair Sultan Maulana (Hashim, 1980) of the Kedah dialect cluster, mentioned above, is also an example of the converging of dialect clusters, namely the Kedah and the Johor-Riau clusters. It also has features, though few, of the Perak cluster. In comparison with Syair Mukomuko and Syair Perang Siak, it has more of the own-feature cluster.

The meeting of dialect clusters is also seen in hikayat, i.e. classical romances, usually with themes centred on a Malay kingdom, where events pertaining to its governance and life within the royal cirlce are narrrated. As the hikayat is the prose counterpart of the syair, the "outsider" cluster that meets the cluster in situ is that of the Johor-Riau variety. This charactersitics applies to the Hikayat Terong Pipit (Oxford University Press, 1964) of the Kedah cluster, which has more such features compared to Syair Sultan Maulana, showing that a prose form can be related in coversational style which opens a wider door to dialectal elements compared to a verse form.

In the observation of Siti Hawa Haji Salleh who edited and discussed Hikayat Patani (Salleh, 1992: p. xxiv), this text is written in standard Malay of the classics (which is rendered in the Johor-Riau dialect), although there are elements of the Patani dialect of Southeastern Thailand. She is of the opinion that that there should be more features of the local dialect, and one may interpret that her idea is to see that this applies to works rendered in the various dialect clusters.

On the other hand, another verse form, the pantun, may be wholly rendered in any speech variety. Even if the Johor-Riau dialect is used, the diction does not include the classical phraseologies that are so characteristic of the hikayat and the syair. See the examples below ${ }^{3}$ :

1) Minangkabau Standard Malay

Pisang ameh bao balaia

Pisang emas bawa belayar

\footnotetext{
${ }^{2}$ William Marsden wasin the service of the East India Company in Bencoolen (i.e. Bangkahulu), as Writer, from 30 May 1771 to 6 July 1779 His exploration of Bangkahulu and other parts is described in his work, The History of Sumatra, published by J. M'creery, Black-HorseCourt, London. The Third Edition was printed in 1811. A Reprint of this edition, Introduced by John Bastin, was published by Oxford University Press, Kuala Lumpur in 1966.

${ }^{3}$ The pantun in the first set is known throughout the Malay-speaking areas of the Malay Archipelago, but rendered in different dialectal forms. The Minangkabauversion is taken from M. Rasjid Manggis, Dt. Radjo Panghoeloe, in his book, Sejarah Ringkas Minangkabau dan Adatnya, published by Penerbit Mutiara, Jakarta, (Rasjid Manggis, 1982: p. 65). The Bengkulu pantun in the second set is the creation of Sari Nande, given in the introduction to her dictionary (Nande, 2012: p. 12).
} 
Pisang lidi di ateh peti

Pisang lidi di atas peti

Utang ameh buliah dibaia

Hutang emas boleh dibayar

Utang budi dibao mati

Hutang budi dibawa mati

2) English translation

Golden bananas are taken on a voyage

Smaller ones on a trunk they lay

A debt of gold can be repayed

That of kindness is taken to the grave

3) Bengkulu Standard Malay

Apé dikaté datuk pengulu

Apa dikata datuk penghulu

Makan gulai naké mudé

Makan gulai nangka muda

Belajola ngécék basé Bengkulu

Belajarlah bercakap bahasa Bengkulu

Mon nak nyatu uang kité galé

Kalau nak satukan orang kita semua

4) English translation

What say honourable leaders

Eating stew of young jack fruit

Learn to speak the Bengkulu tongue

If our unity is the goal

\subsection{Meeting of Peninsula and Sumatera Malay Language Speakers}

Malay speakers have been crossing the Straits of Melaka to and fro from historical times until today. There are several factors which have led to this activity. One is attributed to wanderlust, which seems to be a tradition of the Malays as described in their annals, folktales, and romances. In the language itself there are two words denoting the concept of wanderlust, and these are merantau and berdagang, both meaning to leave one's homeland for some other place, in order to get a better livelihood or education, to look for a wife, or simplyto know "how others live". The meaning of "trade" given to dagang in contemporary Malay came much later, most probably as a result of the activity of buying and selling during the "wandering"4.

It was due to the tradition of merantau or berdagang that today there are Sumateran Malay communities all over the Malay Peninsula. Clear evidence is seen in place names, such as Kampar, Kampung Kerinci, Kampung Minang, etc. Dialect speakers from the same cluster from Sumatera may not converge on one single locality in the host region, but may be found in various parts of the Peninsula. For example, the Kampar dialect community of the Minangkabau cluster is not only located in Kampar (Perak), but also in various places in Pahang, Kedah and Selangor, while the Minangkabau dialect community of the same cluster is not only confined to Negeri Sembilan, as there is also a sizeable community of this dialect in Selangor. Similarly, groups representing the Bengkulu cluster have settled in various places in Kuala Lumpur, Selangor, and Negeri Sembilan. The geographical dispersal of speakers from the same dialect cluster and even from the same dialect is an indication that migration from Sumatera occurred in stages, and that assimilation through language usage and cultural practices means receptivity of the linguistic and cultural traditions of the host community.

\section{The Bengkulu Community of Sungai Choh}

This section focuses on the people originally from the Bengkulu dialect cluster of southwest Sumatera, who

${ }^{4}$ The pantun given below exemplifies the usage of anak dagang with the meaning "outsider" or "foreigner". Anak lang di kayu tinggi, A young eagle high on a tree Patah ranting terbanglah dia; When the branch breaks, it flies away; Anak dagang datang ke sini. The outsider has come to stay, Sampai masa pulanglah dia. When the time comes he returns to his country. In Syair Mukomuko, Syair Perang Siak, and Hikayat Patani, the word dagang is also used with the same meaning. 
have settled in Sungai Choh, Serendah (Selangor), about 50 kilometers from Kuala Lumpur. Both Sungai Choh and Serendah were villages in the early part of the $20^{\text {th }}$ century, but after the Second World War their status changed when there came into existence, for the purpose of administration, 13 subdistricts (mukim) of a larger region of Hulu Selangor which was labelled as district (or daerah) of the Selangor state. A subdistrict encompassing Serendah and Sungai Choh was one of these subdistricts, which took the name of Serendah.

Serendah has a land size of 12,901 hectares, equivalent to 51,647 acres. (Source: District and Land Office, Hulu Selangor 2007). Sungai Chohis situated on the southwestern edge of this subdistrict, about five kilometers from the highway connecting the northern and southern tips of the Malay Peninsula, with Kuala Lumpur in the centre being 50 kilometers away. According to the statistics of 2014, in terms of the number of households Sungai Choh has 1427 as against 4296 in Serendah (Statistics of the National Water Service Commission 2014, in Selangor Kini, 7-14 March 2014).

The population of Hulu Selangor for 2010 was 194, 387, and about 50\%, i.e. 83,099, reside in Serendah. A great majority (about $80 \%$ ) of the people both in Hulu Selangor and all the mukim, including Serendah, are Malays. The non-Malays as given in the statistics are Chinese, Indians and other indigenous groups. In the statistics the Bengkulu Malays are taken together with other Malays in the population, i.e. the local Malays.

\subsection{Choice of Sungai Choh as Locus of Research}

The Bengkulu Malays (hence referred to as Bengkulus) are Malays who originate from Bangkahulu/Bengkulu (or Bencoolen, to use the English term), in West Sumatera. Besides Sungai Choh, there are small communities of them in other parts of Selangor, Kuala Lumpur and Negeri Sembilan. Our choice of Sungai Choh for this research is based on the fact that statistically its population is more numerous compared to those of its sister communities elsewhere in the Peninsula, besides the fact that this community appears to be more "visible" through activities in creating an awareness among its members, of their specific identity as Bengkulus (as opposed to other settler Malay groups, also from Sumatera, such as the Minangkabau, the Kampar, and the Rawa).

Another factor for the choice of Sungai Choh was its closeness to Kuala Lumpur, our home-base, which made it easy for us to meet up with members of the community who were our informants. As we were looking at the bigger picture of the Bengkulu migration to the Peninsula and their settling down where they currently are, rather than the micro-features of their language, we chose community members who were knowledgeable in the history of the settlement, having been recipients of narratives that had been handed down by word of mouth through the generations, besides the fact that they are also the ones who have time to organise socio-cultural activities in their community.

Of the seven members we interviewed, five were 65 years and above, the oldest being 68 . Of the other two, one was 54 years of age, and the other was 35 . All these are women, except for one male informant who was already in his sixties. This unbalanced male: female ratio was brought about by a social situation in which female informants were easily available, as most of them stayed at home after their retirement from jobs previously held in the public and private sectors. As for the men in the community, and probably in other communities as well, retirement may mean occupying themselves in new vocations such as setting up smallscale businesses and being involved in social and political activities which do not give them the privilege of staying at home.

In giving information of a socio-cultural and historical nature, women appear to be good narrators. They are ready talkers and willing to respond to questions posed to them. In this, the women in Sungai Choh are not unique in themselves. This special informant-friendliness, is also present among Malay women in other regions. A group worth mentioning are the Malay women settlers of the Holy City of Mecca interviewed by Asmah Haji Omar in 2014 (see Omar et al., 2015).

\subsection{Background History of Bengkulu Migration}

The Bengkulus must have been coming to the Malay Peninsula from the second half of thenineteenth century as an aftermath of the taking over of Bencoolen by the Dutch from the British in 1824, following the postNapoleonic war treaty of that year which divided the Malay world into regions of Dutch and British hegemonies. Following this treaty, the Dutch and the British exchanged territories: the British leaving Java and Sumatera and all their interests in the islands which are now Indonesia, in exchange for what is now Malaysia, and vice versa. 
British interest in pepper trade where Bencoolen was a major supplier in Sumatera, had brought the British, through the East India Company, to the region. When the British left Bencoolen to concentrate on Singapore and the Malay Peninsula, Malays who had served the company came with them. This was the beginning of the merantau eastward of the Bengkulu people. The merantau increased when they found that forced labour and imposition of tax on the villagers under Dutch rule was unbearable to them. The population of the area around the port of Bencoolen decreased by 50\% not long after the Dutch took over, as depicted in the following passage in Siddik (1996: p. 98).

Pada masa yang silam, penduduk ibu kota ditaksir berjumlah 10,000, namun setelah pengambilalihan dari tangan Inggris, dan lebib-lebih pada masa pemerintahan assisten-residen J. H. Knoerle, banyak penduduk yang pindah meninggalkan Bengkulu sehingga kini jumlahnya susut menjadi 5302 jiwa.

(Translation: Previously, the population of the capital [of Bengkulu] was estimated at 10,000, but after the taking over from the English, and more so during the rule of the Assistant Resident J.H. Knoerle, many of the inhabitants left Bengkulu, and only 5302 remained).

Why the Malay Peninsula? News of good things about the Peninsula, where new settlements were being openedand jobs aplenty especially in the planting of coffee followed by rubber, brought back by their countrymen who had gone there earlier, were too good to ignore. They travelled overland eastwards to the east coast of Sumatera taking days on end, and thence crossed the Straits of Melaka by sailing boats. Some landed in Singapore, while others ventured north until they reached Bukit Lachong, near the present-day Port Kelang.

Our informants in Sungai Choh made it a point to draw our attention to the existence of Bencoolen Street in Singapore, which was proof of the centuries-old connection between their ancestral homeland and the Peninsula. The settlers from Bengkulu in Singapore were able to get good jobs and improved their socio-economic status. There were among them who became Sheikh Haji, i.e. agents for pilgrims going on the Hajj to Mecca. Some of them crossed over to Johor and settled in Muar and Segamat (Abbas, 1967).

Bengkulu settlements in Selangor date back to a period not earlier than the last decade of the $19^{\text {th }}$ century, about half a century after the transfer of Bencoolen to the Dutch. Sungai Choh and Serendah were then two villages adjacent to one another, but for the purpose of this paper Sungai Chohrefers to both of them.

According to the narratives rendered by the informants, the earliest Bengkulu to arrive at this place was one by the name of Haji Rauf, in 1907, with his family. Other families followed soon after. After landing in Bukit Lachong, they headed straight to Sungai Choh and Serendah, where they met with other Sumaterans who were already there much earlier than them. These earlier groups were from Kerinci, Kuantan, Melampa Bonjo, Rawa, and Batang Kapas, who found a living in the building of roads and the railway connecting Kuala Lumpur and the northern states of the Peninsula which began in 1905. Sumaterans from these groups were also among the workers in the opening of the Serendah town in 1894 during the rule of Sultan Abdul Samad (Abbas, 1967: pp. 13-14).

As more and more Bengkulu people arrived, they converged on Sungai Choh, and started rubber and coffee plantations. In time they outnumbered the other Sumateran settlers, some of whom moved on to other parts of Selangor, such as Kuala Kubu Baharu and Kuang. After the Second World War, some of the Bengkulusin Sungai Choh moved out to start afresh in Behrang, Sungai Merab, and Bangi (all in Selangor), Gombak (Kuala Lumpur), and Gemas (Negeri Sembilan). Today Sungai Choh is almost wholly inhabited by Bengkulu Malays, while in Serendah there is a mixed community of Bengkulus and local Malay groups.

The Bengkulu community members of Sungai Choh claim that their ancestors came from Bengkulu or Bangkahulu in Southwest Sumatera, specifically from the district of Lagan, now known as Taba Lagan. According to the narrative handed down to them from their elders, the early Bengkulu people who came to the Malay Peninsula were from different districts which can be identified according to the dialects they spoke, and there were at least nine of them. However, the dialects which claim to have more speakers than others are Bulang, Lembak, and Serawai. In Sumatera, the Bulang dialect is spoken in Kota Bengkulu and the vicinity, while the Lembak dialect is spoken by those living along Sungai Bengkulu, also known as Sungai Serut, and Padang Ulak Tanding in Kabupaten Rejang Lebong. On the other hand, Serawai is the dialect of Southern Bengkulu. According to Nande (2012: p. x), the speech form of the Bengkulu people of Sungai Choh and Serendah is a mixture of Bulang and Lembak, while the Serawai dialect In the Malay Peninsula is spoken by the Bengkulu settlers in Gemas.

When the Bengkulu people of different parts of the Peninsula meet, they refer to themslves by the name of the 
place of origin of their ancestors. For example, the Sungai Choh people refer to themselves as puak Lagan (people of Lagan). Most of them still have connection with relatives there. If there is any connection between Lagan, and the places named as Si Luggan (pronounced lagan) in Marsden's The History of Sumatra (Marsden, 1811, 1966: p. 319), and Selagan in Syair Mukomuko, verses 152 and 222 (Kathirithamby-Wells \& Hashim, 1985), the Lagan people of Sungai Choh must have had a very long history behind them.

In Marsden's account (ibid.) of his travel from the English fort in Bencoolen to Mukomuko, there was a region drained by the Si Luggan River, as quoted below:

Fort Ann lies in the southern and the settlement on the northern side of the Si Luggan river, which name belongs to the place also, and that of Moco-moco to a small village higher up. The bazar consists of one hundred houses, all full of children. At the northern end is the sultan's, which has nothing peculiar to distinguish it, but only its being larger than other Malay houses. (Italics are from the original).

In Syair Mukomuko, Selagan appears to be a place with a chieftain, pengulu, known as Pengulu Yang Lima Kota, who was among those specially mentioned attending the funeral of Sultan Mukomuko's daughter, as given in verses 152 and 222 of the syair.

152. Tiadalah berapa akan lamanya-Not long after

Tibalah Pengulu Yang Lima Kota-Came the chief of five cities

Dari Hulu Selagan tempat datangnya-From up the Selagan river

Air Dikit pula nama bandarnya-A town called Air Dikit

222. Setelah hadir segala pendeta-When all the men of religion arrived

Imam, khatib, (ber) kumpul semuanya-Imam, Khatib were all gathered

Kadi dan sahih dari Menjuto-The Kadhi and Sheikh from Menjuto

Pegawai Selagan pula bersama-Selagan officials included.

According to the Bengkulu people of Sungai Choh, their puak or people have a spiritual power (ilmu batin) that is unmatched by other Bengkulu puak. One of their ancestors by the name of Maripak Ali, also known as Rajak Penyuluh, landed in Kelang with a pair of goats on his shoulders, and he had the power to light up the whole kampong just by pointing out his finger, and by the same method he could cut a bar of iron to small pieces. When their early ancestors came from Lagan they brought with them sevenkris (Malay dagger) with supernatural power. These proved to be useful during the Malayan Emergency period after the Second World War, when they joined the local community to fight the communist terrorists. Today only three of those kris are still left with the community.

A movement known as selendang merah (red sash) which came with their ancestors from Lagan taught them how to empower themselves through the building up of their spiritual strength. This gave them the prowess to help the government fight the enemy during the Emergency period which started in 1948 and continued well into the latter part of the 1960s.

\subsection{Language Maintenance and Shift in the Sungai Choh Community}

There has not been much research done on the socio-cultural life of this community, and even on Bengkulu settlers in other parts of the Peninsula. Where research on linguistics is concerned, only two can be identified so far, and these are academic exercises submitted as a partial requirement for the award of the Bachelor of Arts degree in Malay Studies, University of Malaya. One is on the phonological system of the dialect, specifically the Serawai dialect as spoken in Gemas, and the other is a phonological-cum-lexical study of the Bulang dialect of Sungai $\mathrm{Choh}^{5}$.

The objective of this current study was to assess the extent of the receptivity or otherwise of the Bengkulu settler community of the norms of the local Malay community. With the background information of the meeting of dialect clusters as discussed above, which can be traced through language use in the literary genres of syair and hikayat, our study of the Bengkulu community in Sungai Choh was to see such meeting in real life situation.

\footnotetext{
${ }^{5}$ Both academic exercises were submitted to the Department of Malay Studies, as a partial requirement for the award of the Bachelor of Arts degree. The phonologucal study byZahari bin Zainudin bears the title, Kajian Fonologi Bahasa Bangkahulu (Zainudin, 1986/1987), while the phonological-cum-lexical study is the work of Mohamad Isa bin Mat Jali with the title, Kajian Fonologi dan Leksikal Dialek Bengkulu di Kampung Sungai Choh (Mat Jali, 1998/1999).
} 
The "local Malay community" meant here is not limited to the immediate neighbourhood of the settler people, but extends to the geographical space of the subdistrict of Serendah and to the vicinities of Kuala Lumpur, which form the wider socio-cultural milieu for members of the community in getting educated and be employed in their adopted country. Our theoretical framework is of maintenance and shift. Using this approach, the study is focused on the socio-cultural factors that have given rise to their stance in maintaining their traditional use of language, and in their inclination to shift away from this tradition. Hence, we will not be discussing the microlinguistic aspects of cluster contact.

Maintenance of a language in a community means that there is continual use of this language by the speakers in their day-to-day affairs. Although language is prone to change due to changes in the socio-cultural life of the community, its maintenance may still be there for as long as the core system (of phonology and grammar) is still intact.

Language shift, on the other hand, is the turning away from the use of one's home or community language. However, shift may not all the time be in totality, but may also be partial. In the latter instance, one may find that in certain social domains speakers prefer to maintain their ertswhile use and practice of language, while they shift towards another language in other domains. Communities which have undergone total shift in language may at one point in the development of their social life revert to their original language, a phenomenon which Professor Fishman calls reversing shift (Fishman, 1991).

Our hypothetical questions concerning this community which has existed for about 100 years away from its parent homeland, at the outset of the research, were:

1) Has there been a conscious effort to maintain the speech form of the parent community?

2) To what extent is the shift away, if it exists, from traditional language use of the early settlers?

3) Is there a reversing shift, or just an effort to keep the language alive as an identity of the community?

Our method of data collection was through the tehnique of friendly conversation, bringing in topics that were relevant to our objectives, and thereby allowing the informants to tell their stories freely. The informants of the age 60 and above belonging to the third generation of settlers were born in the 1950s, which means that they attended school before the implementation of the the National Education Policy 1970, at the time when the English school represented mainstream education in Malaya/Malaysia. Hence, they are fluent in standard Malay, English and the local Malay dialect. There was a lot of local Malay-English code-switching in our conversation. The findings of our research are discussed in the following sub-section.

\subsection{Language Use in the Community}

The first and second generations of settlers maintained their Bulang dialect of Bengkulu. Among members of the first generation who arrived at the beginning of the twentieth century were those who had had Islamic religious education while still in Sumatera, and in their new place of abode they were able to join the local community in the teaching of Islam conducted in mosques and madrasah (religious school).

There was no system of compulsory schooling (at the Malay school) at that time. As their livelihood depended on the clearing of swamps and forests, the planting of rubber and coffee, and the building of railways and roads, paper qualification was not a necessity for the first two generations. And coupled with this, there was no necessity to groom themselves to any extent in the local speech form which they could easily acquire through their mingling with local Malays. Slips in the pronunciation of words did not cause a breakdown in communication. If the use of a lexical item happened to cause a misinterpretation, this could be rectified on the spot.

The third generation born after the Second World War were brought up when Malay schools were already well-established providing primary education on the one hand, and the English schools providing secondary education on the other, all over the Peninsula. Hence, they were able to acquire standard Malay in addition to local Malay, and English. The home language with their parents and grandparents was the Bulang dialect, which means that their ancestral speech formwas still maintained in the community. The local Malay dialect was for the purpose of their interaction with the people outside their Bengkulu community, inclusive of the non-Malays, i.e. the Chinese and the Indians. English was the real new addition to their speech repertoire. With their education up to the secondary level, topped by their Malay-English bilingualism, they had a future before them - to further their education at the tertiary level, or to look for jobs which gave them a monthly salary. Indeed, there are those of their community who have risen to high places in the government service and the entertainment world.

When the fourth generation arrived, it was the beginning of the period of the New Education Policy 1970 
which is still in implementation today. In this system, the English schools have been replaced by national schools which provide education from the primary to the secondary level using Malay as the medium of instruction, while English is taught as a subject in the curriculum. With the socio-economic development of the country, life becomes more competitive especially in getting jobs in the public as well as the private sector. The school certificate awarded to successful candidates of the examination by that name, taken at the end of their secondary school education, is a passport to a better life ahead. A good grade in the Malay language paper is a prerequisite to getting admitted into jobs in the public sector, or into post-secondary education, a step in getting into the university or a college giving professional training leading to various vocations. But the chances are better for the individual if he also scores a high grade in English. Parents of the fourth generation understand the situation, and give all encouragement to their children to concentrate on the learning of Malay and English. Seldom do they use the Bulang dialect to interact with their children. Acquisition of this dialect, if it takes place, among members of the fourth generation is through listening to their parents and the elders of the community speaking to each other. Most say they understand what is being said but are not able to respond using the same speech form. Hesitation on their part lies in the pronunciation and the intonation peculiar to the dialect.

Present-day schoolchildren belong to the fifth generation of the Bengkulu community of Sungai Choh. They represent the continuity of being absorbed into the country's system of education which first affected their grand parents (third generation), through to their parents (fourth gneration). The fact that their parents have shifted away from the language of their ancestors means that this speech form does no longer exist as an entity in the community. Its complete "erasure" in the community's life means cutting off the umblical link between them and the parent community in Sumatera. This realisation evokes a feeling of nostalgia of their origin and motivates programmes in teaching the children to speak the Bulang dialect. It is members of the third generation (our informants) who are most active in the regeneration of their basé Bengkulu (Bengkulu language). To quote one of the informants, "Patut belajar bahasa Bengkulu. Anak lahir bahasa Melayu". ("The children should learn the Bengkulu language. They were born with the Malay language.”)

As part of the regeneration programme, Bengkulu spouses from other Malay groups are encouraged through their verbal interaction within the family to use their dialect. When the Governor of Bengkulu in Sumatera visited the community a couple of years ago their interaction with him was in basé Bengkulu.

To sum up, the Bengkulu dialect in Sungai Choh could be maintained up to the third generation, equivalent to a time span of 50 years after it arrived with the first batch of speakers from Sumatera. The first two generations represented a safe period in the life of this dialect as an intra-community language. The southern Peninsula Malay dialect as the speech form in their interaction with local Malays did not interfere with their use of their birth dialect when they were within their own community. And their ability to keep to the situation was also due to the practice of endogamy which was well guarded until the 1960s. This means that they were not in favour of their children taking spouses from outside the group, including those from Sumatera. But the tide of social change which mainly came with education where children of the various ethnic groups mingled freely with one another had no sooner broken the walls of endogamy. As they are Muslims, and like all other Malays, they would only marry Muslims but regardless of race or ethnicity.

Although members of the third generation were able to interact in their dialect in the home and within their own community, outside the home they were making themselves proficient in two other varieties of Malay - the local Malay dialect within the vicinity of their community, and standard Malay which was the variety used in the school. There is not much difference between the two, except that that the latter is more formalised in terms of usage, while the formeris used in conversation in informal situations. Regular use of these varieties, and more so of standard Malay, was a way to ensure that they were accepted by the local community and at the same time succeeded in their school examinations. This was the drive which had the support of their parents. It can be said that diminishing use of the Bengkulu dialect had already begun in the third generation. This process continued in the fourth generation, as this cohort became fully assimilated in the host community.

A community identifies itself with its language (in its abstract meaning), or a speech form, which has been part of its history of civilization. In the case of the Bengkulus of Sungai Choh, its loss means their link with their ancestral homeland has been severed. Efforts in reviving the use of the dialect in the community do not indicate their objective in reversing the shift in the sense of replacing the local Malay dialect, but more as a measure in instilling an awareness of their heritage. This awareness is made more visible with visits to Bengkulu in Sumatera, to re-connect with relatives over there, and such visits are made possible with easier air-travel between Kuala Lumpur and Bengkulu. 


\section{Conclusion}

Contact of dialect clusters is seen in two different contexts. The first is the historical past which is only possible by inference through written literature represented by the syair and the hikayat. Language used in these texts shows the meeting of members of the same dialect cluster as well as members of different clusters. This implies two possibilities. One is that the author is adept at using more than a single variety or dialect of Malay, as in the case of the author of Syair Mukomuko. The other is that two or more authors from different areas of a single dialect or from different dialect clusters are involved in the writing of a syair or a hikayat.

The second context is a real life situation which clearly shows that speakers of a different dialect or dialect cluster are willing to adapt themselves to the linguistic norms of the host community in order to be part of the community. Although their speech form and that of the host community belonged to the same language, adaptation did not come readily due to the fact that there was no necessity for it as a job requirement, and that they were able to mix with the local people where interaction was of a single language but in different forms. From this second context, inference could be made of situations in the past when people of different dialects or different clusters were in contact.

\section{References}

Abbas, Y. B. H. (1967). Perubahan Sistem dan Masharakat Bangkahulu Di-Kampong Sungai Choh Dalam Daerah Ulu Selangor. Academic Exercise for the Bachelor of Arts, Department of Malay Studies, University of Malaya, Kuala Lumpur.

Fishman, J. A. (1991). Reversing Language Shift: The Theoretical and Empirical Foundations of Assistance to Threatened Languages. Clevedon: Multilingual Matters Ltd.

Goudie, D. J. (1989). Syair Perang Siak. Kuala Lumpur: Malayan Branch of the Royal Asiatic Society.

Hashim, M. Y. (1980). Syair Sultan Maulana: Suatu Penilaian Kritis Hasil Pensejarahan Melayu Tradisional. Kuala Lumpur: Penerbit Universiti Universiti Malaya.

Hikayat Terong Pipit (1964). Kuala Lumpur: Oxford University Press.With an Introduction by Asmah Haji Omar.

Kathirithamby-Wells, J., \& Hashim, M. Y. (1985). The Syair Mukomuko: Some Historical Aspects of a Nineteenth Century Sumatran Court Chronicle. Kuala Lumpur: Malaysian Branch of the Royal Asiatic Society, Monograph No. 13.

Marsden, W. (1811, 1966). The History of Sumatra. London: J. M'creery, Black Horse-Court. The Third Edition Was Printed in 1811. A Reprint of This Edition, Introduced by John Bastin, Was Published by Oxford University Press, Kuala Lumpur, 1966.

Mat Jali, M. I. (1998/1999). Kajian Fonologi dan Leksikal Dialek Bengkulu di Kampung Sungai Choh (1998/1999). Academic Exercise for the Bachelor of Arts, Department of Malay Studies, University of Malaya, Kuala Lumpur.

Nande, S. (2012). Kamus Bengkulu: Basé Bengkulu ke Bahasa Malaysia. Serendah: Penerbit Medbaai Reqqa Enterprise.

Omar, A. H. (2008). Susur Galur Bahasa Melayu (2nd ed.). Kuala Lumpur: Dewan Bahasa dan Pustaka.

Omar, A. H. et al. (2012). Bahasa Minangkabau Mukim Sesapan Batu Minangkabau. Kuala Lumpur: Dewan Bahasa.

Omar, A. H. et al. (2015). Malays in the Holy Land: An Ethnolinguistic Study. Kuala Lumpur: University of Malaya Press.

Petyt, K. M. (1980). The Study of Dialect. London: André Deutsch.

Rasjid Manggis, M. (1982). Sejarah Ringkas Minangkabau dan Adatnya. Jakarta: Penerbit Mutiara.

Salleh, S. H. H. (Ed.) (1992). Hikayat Patani. Kuala Lumpur: Dewan Bahasa dan Pustaka.

Siddik, A. (1996). Sejarah Bengkulu 1500-1990. Jakarta: Balai Pustaka.

Zainudin, Z. B. (1986/1987). Kajian Fonologi Bahasa Bangkahulu. Academic Exercise for the Bachelor of Arts, Kuala Lumpur: Department of Malay Studies, University of Malaya. 